\title{
Traversal Tree Implementation in Chart of Account Design
}

\author{
Monika Handayani*, Muhammad Hendra, Muhammad \\ Bahit \\ Dept. Computerized of Accounting, Faculty of Accounting \\ Politeknik Negeri Banjarmasin \\ Banjarmasin, Indonesia \\ *monika_handayani@poliban.ac.id,Hendra@poliban.ac.id, \\ bahit@poliban.ac.id
}

\author{
Noor Safrina \\ Dept. Accounting, Faculty of Accounting \\ Politeknik Negeri Banjarmasin \\ Banjarmasin, Indonesia \\ Safrina@poliban.ac.id
}

\begin{abstract}
This study aims to create a control of account (CoA) with the tree preorder traverser method with the development of the MPTT (Modified preorder tree traversal) method to facilitate the recording of financial information systems. The way that is now used to create an account is the manual way to analyze the creation of a structured account, so the computing process takes a long time for each transaction process. To provide solutions to these problems, the researchers used the tree traversal algorithm method. The results of this study are the chart of accounts $(\mathrm{CoA})$. CoA is very important by using the MPTT method because it can complete the computational process in a shorter time compared to the manual way especially if the CoA data is used in large numbers by determining the relationship of each account with $\mathrm{CoA}$.
\end{abstract}

Keywords: control of account (CoA), modified preorder tree traversal

\section{INTRODUCTION}

Changes in the economic globalization, impact on financial information based on information technology (IT) is a new challenge in financial information systems [1]. The more advanced IT development, the more access to various types of financial information systems [2]. The role of IT in the field of financial information can help managers and finance in making decisions related to the provision of information and financial transactions that are supported and translated [3]

Financial information system is also responsible for maintaining or recording all financial transactions that occur in the company, including the movement of assets in and out, such as preparation, operating costs, reporting sales and purchases [4]. A complete financial information system every financial transaction and cash flow in the company [5]. Financial information systems need to pay attention to processes such as creating accounts, regulating accounting periods, keeping journals in order to produce systematic financial reports [6]. Financial statements are considered systematic if they have a good chart of account (CoA) so as to facilitate the search for financial statement transactions. CoA is a process for classifying transaction accounts so that they are easy to understand and remember, and control journals and financial reports [7].

Previous research has made a CoA with enterprise requirements planning (ERP) system with the aim of making transaction account charts from manual to automatic [8]. However, this research does not analyze the structure of each code in the financial transaction account and ERP implementation is only suitable for medium and large companies. The existence of an account structure or account control (CoA) can help computing processes carried out by computers run quickly. This can provide information to companies quickly and accurately. Enterprise resource planning in the field of accounting is the process of determining the provision of information in accordance with accurate financial transactions in corporate financial reporting. Financial statements that contain every transaction that occurs in the company by creating a different account for each financial transaction such as asset transactions in and out, such as payments, operating costs, sales and purchase reporting.

\section{LITERATURE REVIEW}

Literature review related to implementation of control of account $(\mathrm{CoA})$ with the traversal tree algorithm needs to be done to determine the extent of previous studies have been carried out or published.

\section{A. Control of Account (CoA)}

Control of account $(\mathrm{COA})$ is the process of classifying transaction accounts so they are easy to understand and remember, and control journals and financial statements [7]. In general, $\mathrm{CoA}$ is the basis for making accounting modules and contains general ledger account summaries [9]. CoA also becomes the main base in the accounting module besides the period, because it controls journals and financial reports [7]. There are several ways to create a CoA such as adding an account combination submodule. 


\section{Implement CoA for MPTT}

CoA Accounts for Parent and Child have been completed, MPTT

The account is already registered, then determine which parent and child. To do this, each account is given a code with a numeric number that has become a condition in making CoA. After all CoA accounts are known which are parent and child, the CoA account is then applied to the MPTT method to determine the left and right of each $\mathrm{CoA}$ account. The following is a list of CoA accounts that have been determined parent and child.

TABLE II. RELATIONSHIP OF COA WITH MPTT

\begin{tabular}{|l|l|}
\hline \multicolumn{1}{|c|}{ Parent } & \multicolumn{1}{c|}{ Child } \\
\hline \multirow{2}{*}{ Assets } & Current assets \\
\cline { 2 - 2 } & Non-current Assets \\
\hline \multirow{2}{*}{ Capital } & Capital stock \\
\cline { 2 - 2 } & Retain earning \\
\hline \multirow{2}{*}{ Debt } & Short-term liabilities \\
\cline { 2 - 2 } & Long-term liabilities \\
\hline
\end{tabular}
the next step is to approve the CoA model in the MPTT method. For CoA implementation in MPTT the model can be seen in figure below.

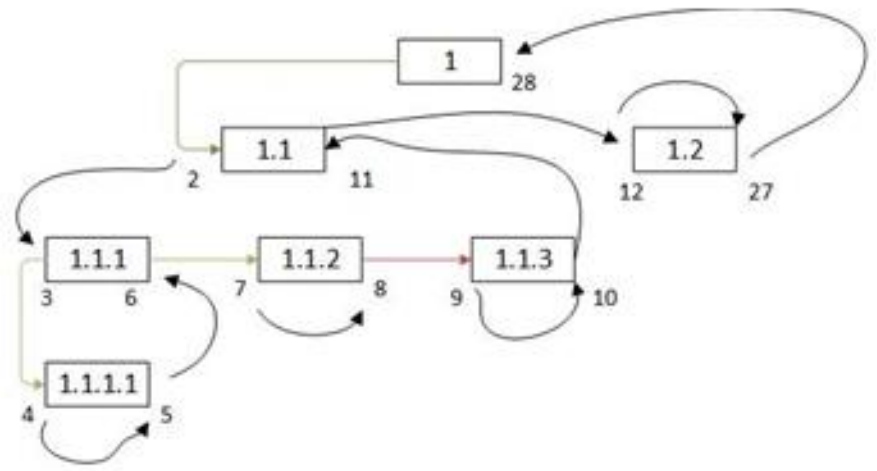

TABLE III. LINKAGES OF ASSET ACCOUNTS WITH MPTT

\begin{tabular}{|l|l|}
\hline \multicolumn{1}{|c|}{ Parent } & \multicolumn{1}{c|}{ Child } \\
\hline \multirow{4}{*}{ Current Assets } & Assets and Cash Equivalents \\
\cline { 2 - 2 } & Account Receivables \\
\cline { 2 - 2 } Non-current Assets & Other receivables \\
\hline \multirow{5}{*}{} & Fixed assets \\
\cline { 2 - 2 } & Investment Property Assets \\
\cline { 2 - 2 } & Non-current Assets \\
\cline { 2 - 2 } & Deferred charges \\
\cline { 2 - 2 } & Intangible Assets \\
\cline { 2 - 2 } & Other Assets \\
\cline { 2 - 2 } & Deferred tax assets \\
\hline
\end{tabular}

TABLE IV. LINKAGES OF CAPITAL ACCOUNTS WITH MPTT

\begin{tabular}{|l|l|}
\hline \multicolumn{1}{|c|}{ Parent } & \multicolumn{1}{c|}{ Child } \\
\hline Capital Stock & - \\
\hline Retain earning & User Defined \\
\cline { 2 - 2 } & Not yet determined by the user \\
\hline
\end{tabular}

TABLE V. LINKAGES OF LIABILITY WITH MPTT

\begin{tabular}{|l|l|}
\hline \multicolumn{1}{|c|}{ Parent } & \multicolumn{1}{c|}{ Child } \\
\hline \multirow{5}{*}{ Short-term liabilities } & Middle Term Loans \\
\cline { 2 - 2 } & Accounts payable \\
\cline { 2 - 2 } & Bank Debt \\
\cline { 2 - 2 } & Tax debt \\
\cline { 2 - 2 } & Advances From Customers \\
\cline { 2 - 2 } & Accrued cost \\
\cline { 2 - 2 } & Debt to Purchase Installments \\
\cline { 2 - 2 } & Other Current Liabilities \\
\hline \multirow{5}{*}{ Long-term liabilities } & Post-employment \\
& Liabilities \\
\cline { 2 - 2 } & Deferred Tax Liabilities \\
\cline { 2 - 2 } & Debt to Purchase Installments \\
\cline { 2 - 2 } & Medium Term Loans \\
\cline { 2 - 2 } & Long-term Bank Loans \\
\hline
\end{tabular}

\begin{tabular}{|l|l|l|l|}
\hline Parent & Title & Left & \multicolumn{1}{c|}{ Right } \\
\hline 1 & 1.1 & 2 & 11 \\
\hline 1.1 & 1.1 .1 & 3 & 6 \\
\hline 1.2 & 1.1 .1 .1 & 4 & 5 \\
\hline 1.3 & 1.1 & 7 & 8 \\
\hline & 1.1 & 9 & 10 \\
\hline 2 & 1.2 & 12 & 27 \\
\hline 2 & 1.2 .1 & 13 & 14 \\
\hline 2 & 1.2 .2 & 15 & 16 \\
\hline 2 & 1.2 .3 & 17 & 18 \\
\hline 2 & 1.2 .4 & 19 & 20 \\
\hline 2 & 1.2 .5 & 21 & 22 \\
\hline & 1.2 .6 & 23 & 24 \\
\hline
\end{tabular}

\section{Implementation of Database Design}

RDBMS (relational database management system) used by MySQL because it is an open source DBMS relational product that is stable, reliable and reliable in handling multi-user connections. This database is able to handle applications that use connectivity in a large number of users. Besides that, MySQL also has a transaction feature, especially when implementing the InnoDB engine. Transaction features in accounting are important so that data consistency occurs if the 


\section{G. CoA Implementation Output Results in the MPTT Method}

The next ways after the system is finished, it then tests whether the output of the MPTT method matches the registered CoA data such as account, parent, child, left and right code. The output of the CoA implementation results in the MPTT method can be seen in table 8 below.

TABLE VIII. OUTPUT OF COA IMPLEMENTATION OF MPTT METHOD

\begin{tabular}{|l|l|l|l|l|l|}
\hline id & \multicolumn{1}{|c|}{ account } & \multicolumn{1}{c|}{ code } & lft & rgt & Parent \\
\hline 1 & Asset & 1 & 1 & 28 & 0 \\
\hline 2 & Equity & 2 & 29 & 38 & 0 \\
\hline 3 & Liabilities & 3 & 39 & 74 & 0 \\
\hline 4 & Current Assets & 1.1 & 2 & 11 & 1 \\
\hline 5 & Non Current Assest & 1.2 & 12 & 27 & 1 \\
\hline 6 & Cash and Cash Equivalent & 1.1 .1 & 3 & 6 & 4 \\
\hline 7 & Trade Receivables & 1.1 .2 & 7 & 8 & 4 \\
\hline 8 & Other Receivables & 1.1 .3 & 9 & 10 & 4 \\
\hline 9 & Fix Assests & 1.2 .1 & 13 & 14 & 5 \\
\hline 10 & Current Liabilities & 3.1 & 40 & 61 & 3 \\
\hline 11 & Non Current Liabilites & 3.1 .1 & 41 & 42 & 10 \\
\hline 12 & Trade Payable & 3.1 .2 & 43 & 48 & 10 \\
\hline 13 & Thirs Parties & 3.1 .1 .1 & 44 & 45 & 12 \\
\hline 14 & Related Parties & 3.1 .1 .2 & 46 & 47 & 12 \\
\hline
\end{tabular}

\section{CONCLUSION}

CoA are a fundamental part of accounting information systems. One method in designing a COA is to use MPTT. MPTT is a method of algorithm that is very fast in facilitating the creation of a framework of linkages between categories which in this case can be applied for COA design. besides in the context of COA MPTT also in accounting information systems can be applied in making hierarchical systems between branch offices. The MPTT method also facilitates management in making financial statements systematically so that it can facilitate the search for financial statement transactions.

\section{ACKNOWLEDGMENT}

The programming language that we use in this study is PHP. PHP is a language used for web-based applications, is open source and reliable on applications used in the scope of network applications. In implementing MPTT we use the Zebra MPTT library. Besides using zebra MPTT we also use the Idiorm library. Idiorm is a library that can be used for database storage with protection features against SQL injection and with the paradigm of a simple and easy database modification process.

The application of hierarical data to the chart of accounts, management and data acquisition is very easy. The MPTT library also applies a table lock mechanism to ensure that data integrity is maintained. This will certainly reduce costs in the process of developing a computerized accounting information system both in the form of time, costs, and in the form of code inefficiencies, thereby reducing the bugs that may occur because COA is the root of transaction processing in accounting. Besides that, using the MPTT method makes account storage unlimited and more flexible in contrast to COA design techniques with methods that have been ascertained against the number of children on a COA account.

\section{REFERENCES}

[1] I. Santouridis, E. Tsifora, P. Trivellas, and S. Nikolopoulos, "Revising Greek Accounting \& Finance Education in an economic crisis environment," Procedia - Soc. Behav. Sci., vol. 148, pp. 428-436, 2014.

[2] I. Santouridis, "Incorporating Information Technology into Accounting and Finance Higher Education Curricula in Greece," Procedia Econ. Financ., vol. 33, no. 15, pp. 432-438, 2015.

[3] M.A. Adhitama, R. Sarno, and Sarwosri, "Account charting and financial reporting at accounting module on Enterprise Resource Planning using tree traversal algorithm," in 2016 International Conference on Information \& Communication Technology and Systems (ICTS), 2016, pp. 20-25.

[4] D. Sunaryono, R. Sarno, V. Hariadi, and Y. Kurniawan, "Perancangan dan Pembangunan Perangkat Lunak Berorientasi Arsitektur Servis (SOA) Dengan Pendekatan Workflow Pada Domain Cash Bank dan General Ledger ERP," SESINDO 2013, 2013. 
[8] P.Y. Wang, T.W.S. Chow, and C.W.F. Chiu, "Computational accounting in determining Chart of Accounts using nominal data analysis and concept of entropy," Expert Syst. Appl., vol. 36, no. 3 PART 2, pp. 6966-6977, 2009.

academics in the boardroom on the value relevance of financial reporting information," Int. Rev. Financ. Anal., vol. 45, pp. 18-30, 2016.

[6] E. Moral-Benito and O. Roehn, "The impact of financial regulation on current account balances,” Eur. Econ. Rev., vol. 81, pp. 148-166, 2016.

[7] D. Cho and A. Doblas-madrid, "Business cycle accounting East and West : Asian finance and the investment wedge," Rev. Econ. Dyn., vol. 16 , no. 4, pp. 724-744, 2013.

[9] H. Averkamp, Accounting Coach. [Online]. Retrieved from https://www.accountingcoach.com/chart-of-accounts/outline, accessed on 18 April 2019.

[10] E.N. Adams, "Another representation of binary tree traversal," Inf. Process. Lett., vol. 2, no. 2, pp. 52-54, 1973. 